\title{
Irrigation Scheduling for Tropical Fruit Groves in South Florida 1
}

Kati W. Migliaccio and Yuncong $\mathrm{Li}^{2}$

\section{Introduction}

Irrigation is used primarily to satisfy plant water needs that are not met by rainfall. Although south Florida receives around 55 inches of rainfall a year, the rain is not equally distributed throughout the year (Figure 1). In fact, south Florida is often described as having a wet season and dry season environment with two-thirds of the total rainfall occurring between May and October.

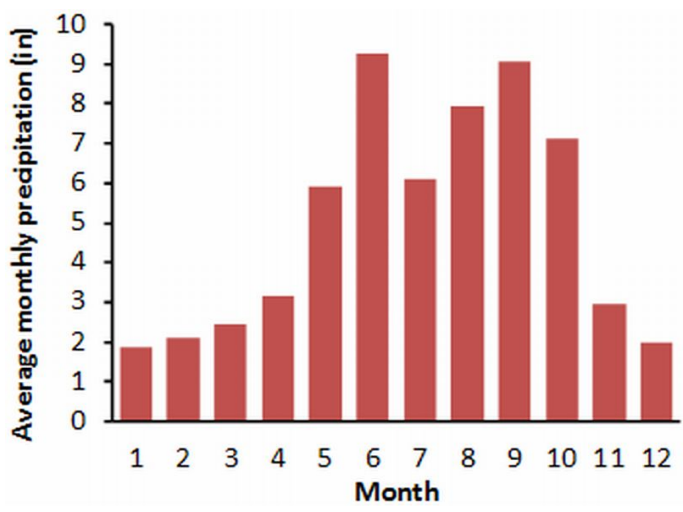

Figure 1. Average monthly precipitation measured at Miami International Airport 1948 to 2008. (National Climatic Data Center, 2008). Credits: Kati Migliaccio
Irrigation is also necessary for soil that cannot store large volumes of water. Most tropical fruit trees in south Florida are grown on gravelly or sandy soils, which have very low water holding capacities. Soil water holding capacity is defined as the amount of water that can be held by soil against the force of gravity (for practical purposes, field capacity is essentially the same as soil water holding capacity). In other words, it is the amount of water the soil can hold without any percolation losses. Thus, soils with a high water holding capacity store more water for plant use than soils with a low water holding capacity. Common soil water holding capacities for soils of south Florida are provided in Table 1.

Table 1. Soil water holding capacities (inches of water per foot of soil depth) for various soil types.

\begin{tabular}{ccc}
\hline Soil & $\begin{array}{c}\text { Range } \\
\text { (in/ft) }\end{array}$ & $\begin{array}{c}\text { Average } \\
\text { (in/ft) }\end{array}$ \\
\hline Gravelly loam & $1.0-1.4$ & 1.2 \\
Marl & $1.2-2.4$ & 1.8 \\
Peats and mucks & $2.0-3.0$ & 2.5 \\
Sand or fine sand & $0.4-1.0$ & 0.75 \\
\hline
\end{tabular}

The precipitation characteristics and soil properties of south Florida are unique and therefore

1. This document is Fact Sheet TR001, Florida Cooperative Service, Institute of Food and Agricultural Science, University of Florida. Publication date: May 2000. Revised January 2009. Please visit the EDIS website at http://edis.ifas.ufl.edu.

2. K.W. Migliaccio, Assistant Professor and Y.C. Li, Professor, Tropical Research and Education Center, Homestead, FL. Cooperative Extension Service, Institute of Food and Agricultural Sciences, University of Florida, Gainesville, FL 32611

The Institute of Food and Agricultural Sciences (IFAS) is an Equal Opportunity Institution authorized to provide research, educational information and other services only to individuals and institutions that function with non-discrimination with respect to race, creed, color, religion, age, disability, sex, sexual orientation, marital status, national origin, political opinions or affiliations. U.S. Department of Agriculture, Cooperative Extension Service, University of Florida, IFAS, Florida A. \& M. University Cooperative Extension Program, and Boards of County Commissioners Cooperating. Millie Ferrer-Chancy, Interim Dean 
should be included when determining an optimal irrigation schedule. The Web Soil Survey (WSS) provides soil data and information produced by the National Cooperative Soil Survey. It is operated by the USDA Natural Resources Conservation Service (NRCS) and provides access to the largest natural resource information system in the world. Information regarding soil types can be found on the NRCS website at http://websoilsurvey.nrcs.usda.gov/app or by using a County Soil Survey Book which are available at local USDA NRCS offices.

The optimal irrigation schedule is defined for this publication as the irrigation schedule that ensures that tropical fruit trees experience minimal water stress and that results in minimal water waste due to percolation or runoff losses.

Depending on the tree species, trees may or may not show visible symptoms of water stress. However, by the time symptoms of water stress are visible to the eye it is often too late to achieve complete recovery.

Multiple tools are available for determining an optimum irrigation schedule that accounts for the unique conditions in south Florida groves.

Irrigation Scheduling Tools

\section{Tensiometer}

This device directly measures soil water potential or tension in the root zone (Figure 2). Tensiometers must be properly installed and maintained to effectively be used for scheduling irrigation (Figure 3). Tensiometers measure soil water tension in pressure units such as cbars $(1 \mathrm{cbar}=$ 0.01 bar, 1 bar $=14.5 \mathrm{psi}$ ).

In general, the following guidelines can be used to interpret tensiometer readings for irrigation scheduling in gravelly or sandy soils:

1) Tensiometer readings of 0 to 8 cbars: the soils are saturated or nearly saturated as a result of recent rain or irrigation. Irrigation should be

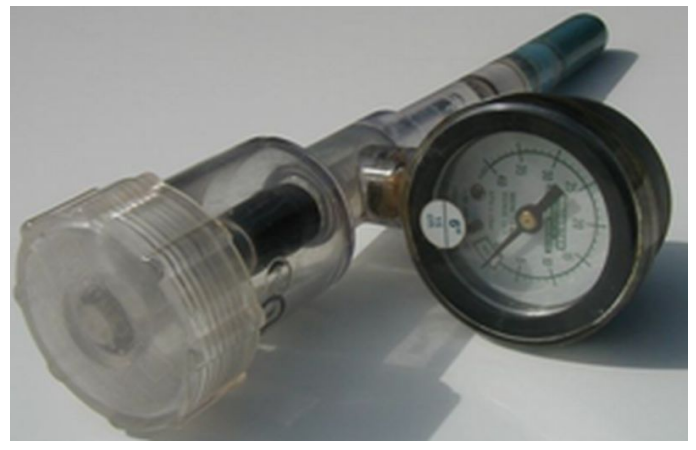

Figure 2. Tensiometer before being installed in the field. Credits: Harry Trafford

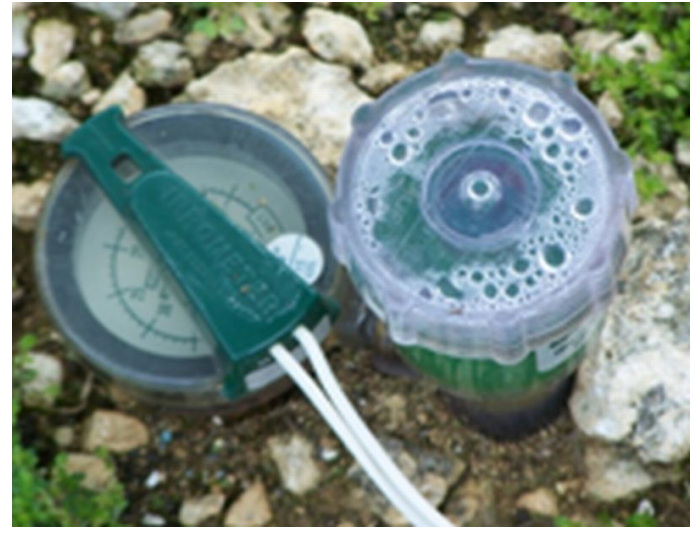

Figure 3. Tensiometer installed in very gravelly loam soil. Credits: Kati Migliaccio

discontinued to prevent water waste and nutrient leaching through percolation or runoff.

2) Tensiometer readings of 10 to 20 cbars: the crops should be irrigated to water holding capacity or to 0 to 5 cbars. Irrigation should be initiated at 10 to 15 cbars during flowering and fruit set and at 15 to 20 cbars at other times.

3) Tensiometer readings of 30 cbars and greater: the plants are likely experiencing water stress and should be irrigated immediately.

Tensiometers can be purchased as stand-alone sensors or can be purchased with magnetic switches that allow the device to trigger irrigation only when the soil tension exceeds the set point (Figure 3).

For additional information on tensiometers see Smajstrla and Harrison (2002) http://edis.ifas.ufl.edu/AE146, and Smajstrla and Pitts (2005) http://edis.ifas.ufl.edu/AE086. 


\section{Capacitance probe}

Many different companies sell capacitance based probes that are designed to be used to measure soil water volumetric content. The suitability of these devices varies and care should be taken in selecting a device for irrigation; specifically, the device should be appropriate for the soil type and should have been rigorously tested. Extension specialists can help with the selection of an appropriate capacitance probe. The instrument takes advantage of the fact that the dielectric constant of water is 100 , that of air is 1 and that of dry soil is in the range of 4 to 6 . The dielectric constant describes the ability of a substance to hold electrical charge. Therefore soils that contain greater volumetric water contents will have a greater dielectric constant which can be measured electronically. The probe measures the electrical capacitance of the surrounding soil-air-water mixture and converts this reading into the percentage of water in soil. Capacitance probes may consist of one sensor or multiple sensors. An example of a multi-sensor capacitance is depicted in Figure 4 and Figure 5.

The probes provide real-time assessment of soil water content. Thus, the data are related to the characteristics of the area in which it is installed. Data from one orchard should not necessarily be used to manage other orchards because soil and water characteristics may be substantially different among sites.

\section{Evapotranspiration}

Evapotranspiration refers to the evaporation and transpiration losses from the orchard. Water requirements of trees can be calculated by determining these losses using reference evapotranspiration (ET) data (Table 2). Reference ET is a value calculated from multiple weather parameters such as temperature, wind and solar radiation (Clark et al., 2002).

Actual evapotranspiration (ETA) is determined by multiplying the cropping coefficient $(\mathrm{KC})$ by the reference $\mathrm{ET}\left(\mathrm{ET}_{\mathrm{R})}(\mathrm{Eq} 1)\right.$.

$$
E T_{A}=K_{C} E T_{R}
$$

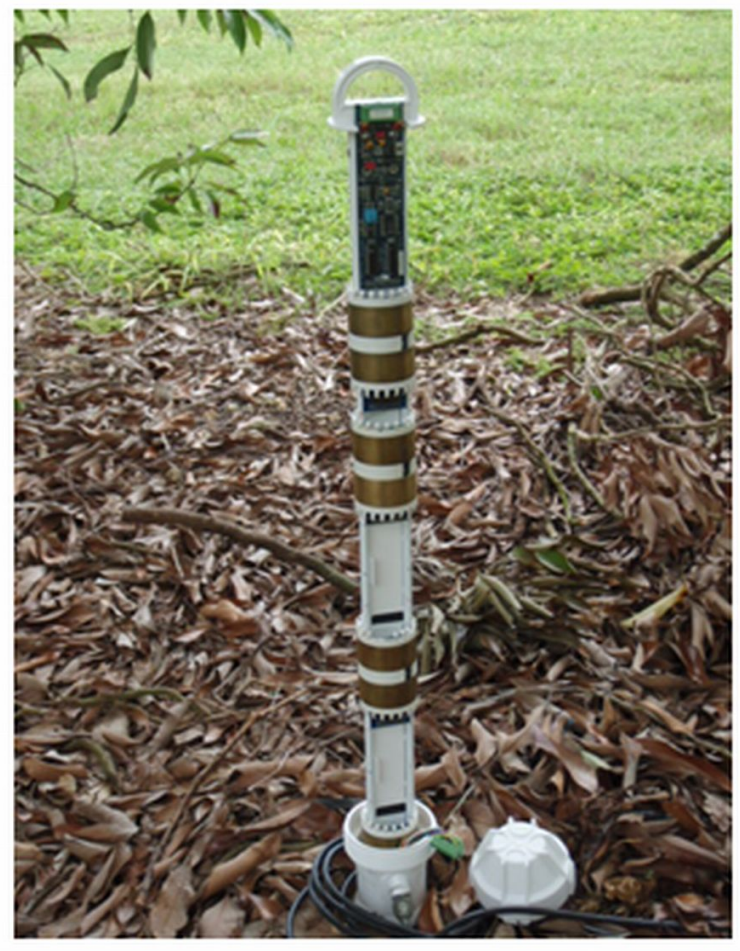

Figure 4. Multi-sensor capacitance probe being inserted into field. Credits: Luis Barquin

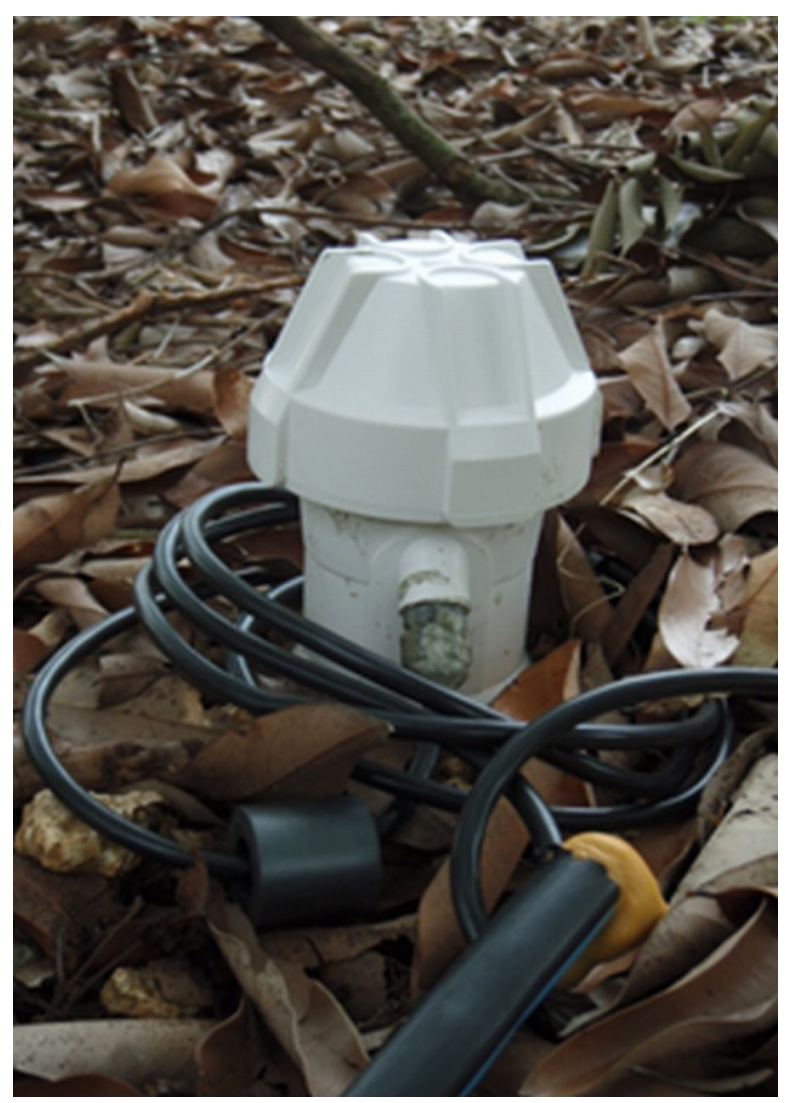

Figure 5. Multi-sensor capacitance probe installed in a south Florida grove. Credits: Luis Barquin 
Irrigation Scheduling for Tropical Fruit Groves in South Florida Soil water holding capacity is generally very low 4 in sandy or gravelly solls (1able 1), which are

Table 2. Estimated average daily reference evapotranspiration (ET) for south Florida.

\begin{tabular}{cc}
\hline Month & Inches/day \\
\hline January & 0.10 \\
February & 0.13 \\
March & 0.16 \\
April & 0.19 \\
May & 0.19 \\
June & 0.18 \\
July & 0.18 \\
August & 0.17 \\
September & 0.15 \\
October & 0.14 \\
November & 0.12 \\
December & 0.10 \\
\hline
\end{tabular}

The irrigation rate is then described by Eq 2 .

$$
1=E T_{\mathrm{A}} R
$$

where $\mathrm{I}$ is irrigation and $\mathrm{R}$ is rainfall. Daily $\mathrm{ET}_{\mathrm{R}}$ values are provided by the Florida Automated Weather Network (FAWN) for locations throughout Florida. This information is located on the FAWN website (http://fawn.ifas.ufl.edu/) in the'Tools' drop down menu. The $\mathrm{K}_{\mathrm{C}}$ values differ among crops and should be diligently calculated and changed throughout the year. Current $\mathrm{K}_{\mathrm{C}}$ values for tropical fruit crops under south Florida conditions have not been sufficiently researched. Extension specialists or agents within your geographical area can offer suggestions for $\mathrm{K}_{\mathrm{C}}$ values.

Irrigation rates can easily be calculated using the ET method. This approach is described in Table 3. It is important to note that this is just an example and each location should be evaluated according to its specific characteristics. commonly found in south Florida. With any irrigation schedule, irrigation water should bring the soil moisture up only to the available water capacity as volumes above this amount will be lost to percolation, runoff, or evaporation. In general, the amount of water available to the trees depends on the soil water holding capacity, the area of water application, and the volume of the root zone.

Root zone depth can typically be determined by knowing the depth of the trench in the orchard. For an established orchard, roots will be found throughout the trenched area. Trenches are typically 24 inches deep and 16 inches wide. Additional roots form a 'pancake' like layer in the plowed soil which is the area where most active roots are found. The plowed soil is typically 5 to 6 inches deep. If irrigation is managed to consider the trenched depth, over irrigation will occur on locations without trenching, and will result in a portion of irrigation water not being used by the fruit tree.

Some irrigation systems do not cover the entire field but rather focus on areas where roots are located. The area receiving spray from this type of irrigation system is termed 'wetted perimeter'. The wetted perimeter can be measured by turning on the irrigation and using a measuring device to determine the diameter of the wetted area. It is important to remember that the height of the micro-jet or other sprinkler device influences the wetted perimeter. To determine the area from the diameter measured, see equation 3 .

Table 3. Calculation of irrigation using the ET method to analyze a one week period of sprinkler irrigation during the month of May using sprinkler irrigation.

\begin{tabular}{lc}
\hline Steps & Answers \\
\hline Step 1. Select the appropriate a $\mathrm{K}_{C}$ value. & $\mathrm{K}_{\mathrm{C}}=1.1$ \\
Step 2. Calculate $\mathrm{ET}_{\mathrm{A}}$ using eq 1. & $\mathrm{ET}_{\mathrm{A}}=1.1^{*} 0.19=0.21 \mathrm{in} /$ day \\
Step 3. Calculate Irrigation (or I) using eq 2 and also accounting for 0.5 inches \\
of rain (or R) for the week period. & $\mathrm{I}=(0.21 \mathrm{in} / \text { day) })^{\star} 7$ days $-0.5 \mathrm{in}=0.97 \mathrm{in}$ \\
Step 4. Determine the irrigation system delivery rate. & $0.25 \mathrm{in} / \mathrm{hr}$ \\
Step 5. Determine time needed to run irrigation for the week (Step 3 / Step 4). & $3.9 \mathrm{hrs}$ \\
Step 6. Determine time needed to run irrigation when there are 2 irrigation \\
events (step 5 / 2).
\end{tabular}




$$
\mathrm{A}=3.14(\mathrm{D} / 2)^{2}
$$

where $\mathrm{A}$ is the area and $\mathrm{D}$ is the diameter. If the diameter is units of feet, then the area (A) calculated is in units of square feet. This value can be used to convert irrigation delivery rates that are in volumes (such as gph) into rates that are in lengths per time (such as in/hr). Irrigation rates can easily be measured in the field using a volumetrically marked container and a stop watch. The irrigation would be initiated and once the system was pressurized a volume of water would be collected from an emitter and timed. This provides you with an estimate of the water delivered. Another method would be to use a catch-can type of approach. For more information on this approach see Smajstrla et al. (2005). Examples for sandy soils and for gravelly soils are provided in Tables 4 and 5 for hypothetical situations. (Note: These are just examples and each irrigation system should be evaluated in terms of its unique characteristics.)

\section{References}

Clark, G.A., and A.G. Smajstrla, and F.S. Zazueta. 2002. Atmospheric Parameters Which Affect Evapotranspiration (CIR822). Gainesville: University of Florida Institute of Food and Agricultural Sciences, University of Florida. [10/15/2008]. Available from: http://edis.ifas.ufl.edu/document_ae037

National Climatic Data Center, 2008. NOAA Satellite and Information Service, National Environmental Satellite, Data, and Information Service. Accessed: October 2008. http://www.ncdc.noaa.gov/oa/ncdc.html

Smajstrla, A.G. and D.J. Pitts. 2005. Tensiometer Service, Testing and Calibration (BUL319) Gainesville: University of Florida Institute of Food and Agricultural Sciences, University of Florida. [10/15/2008]. Available from: http://edis.ifas.ufl.edu/document_ae086

Table 4. Calculation of irrigation considering soil water holding capacity in a sandy soil using micro-jet irrigation.

\begin{tabular}{|c|c|c|}
\hline Steps & Source of information & Example answers \\
\hline Step 1. Determine the soil water holding capacity. & Knowledge of soil, soil survey maps, Table 1 & 0.75 in water / ft soil \\
\hline Step 2. Determine root zone depth. & Knowledge of field & $2 \mathrm{ft}$ \\
\hline Step 3. Determine wetted perimeter diameter. & Measured in the field as described in text & $10 \mathrm{ft}$ \\
\hline Step 4. Calculate area of wetted perimeter & Area $=3.14^{*}(\text { diameter } / 2)^{\wedge} 2$ & $78.5 \mathrm{ft}^{2}$ \\
\hline Step 5. Determine irrigation delivery rate. & Measured in the field as described in text & $21 \mathrm{gph}$ \\
\hline Step 6. Convert units of step 5 to cubic feet. & 7.48 gallons $=1 \mathrm{ft}^{3}$ & $2.81 \mathrm{ft}^{3} / \mathrm{hr}$ \\
\hline Step 7. Determine irrigation rate in inches per hour. & Divide step 6 by step 4 and multiply by 12 & $0.43 \mathrm{in} / \mathrm{hr}$ \\
\hline $\begin{array}{l}\text { Step } 8 \text {. Time to reach soil water holding capacity if } \\
\text { irrigation begins when water is } 50 \% \text { depleted in } \\
\text { soil. }\end{array}$ & $(50 \%)^{*}$ step $1{ }^{*}$ step $2 /$ step7 & $1.7 \mathrm{hrs}$ \\
\hline
\end{tabular}

\section{Summary}

Irrigation scheduling can be accomplished using different tools. Each tool has its benefits and weaknesses (Table 6). It is critical to use each tool as it is intended to ensure an optimum irrigation scheduling is achieved that will benefit tropical fruit trees.
Smajstrla, A.G. and D.S. Harrison. 2002. Tensiometers for Soil Moisture Measurement and Irrigation Scheduling (CIR487). Gainesville: University of Florida Institute of Food and Agricultural Sciences, University of Florida. [10/15/2008]. Available from: http://edis.ifas.ufl.edu/document_ae146

Smajstrla, A.G., B.J. Boman, G.A. Clark, D.Z. Haman, D.J. Pitts, and F.S. Zazueta. 2005. Field Evaluations of Irrigation Systems: Solid Set or Portable Sprinkler Systems. (BUL266). Gainesville: 
Table 5. Calculation of irrigation considering soil water holding capacity in a gravelly soil using sprinkler irrigation.

\begin{tabular}{lcc}
\hline \multicolumn{1}{c}{ Steps } & Source of information & Example answers \\
\hline Step 1. Determine the soil water holding capacity. & $\begin{array}{c}\text { Knowledge of soil, soil survey } \\
\text { maps, Table 1 }\end{array}$ & $\begin{array}{c}\text { Knowledge of field } \\
\text { Step 2. Determine active root zone depth. }\end{array}$ \\
$\begin{array}{l}\text { Step 3. Determine irrigation delivery rate. } \\
\text { Measured in the field as } \\
\text { described in text }\end{array}$ & $\begin{array}{c}0.5 \mathrm{ft} \\
(50 \%)^{*} \text { step 1*step 2/ step3 }\end{array}$ \\
$\begin{array}{l}\text { Step 4. Time to reach soil water holding capacity if irrigation } \\
\text { begins when water is 50\% depleted in soil. }\end{array}$ & $1.2 \mathrm{hr}$ \\
\hline
\end{tabular}

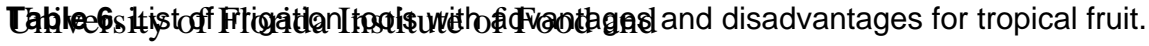

\begin{tabular}{|c|c|}
\hline 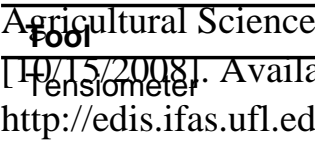 & 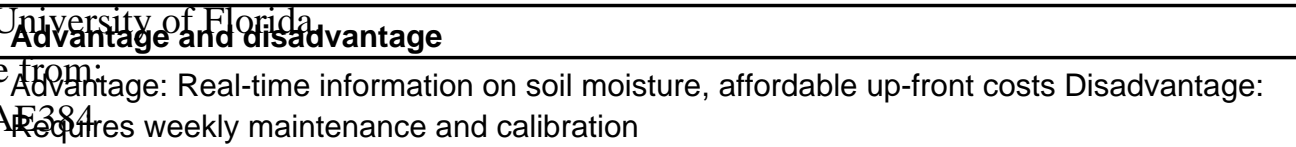 \\
\hline Capacitance probes & $\begin{array}{l}\text { Advantage: Real-time information on soil moisture } \\
\text { Disadvantage: Expensive up-front costs, wiring required, maintenance of probes require } \\
\text { constant calibration. }\end{array}$ \\
\hline Evapotranspiration & $\begin{array}{l}\text { Advantage: Minimum up-front costs, daily data free from FAWN } \\
\text { Disadvantage: Must know crop coefficients, need for site specific data (radiation, wind speed, } \\
\text { etc.) }\end{array}$ \\
\hline $\begin{array}{l}\text { Soil water holding } \\
\text { capacity }\end{array}$ & $\begin{array}{l}\text { Advantage: Minimum up-front costs } \\
\text { Disadvantage: Use requires knowledge of all factors influencing soil moisture }\end{array}$ \\
\hline
\end{tabular}

